\title{
High-temperature requirement factor A1 rs11200638 polymorphism and age- related macular degenerative from a comprehensive analysis about 15316 subjects
}

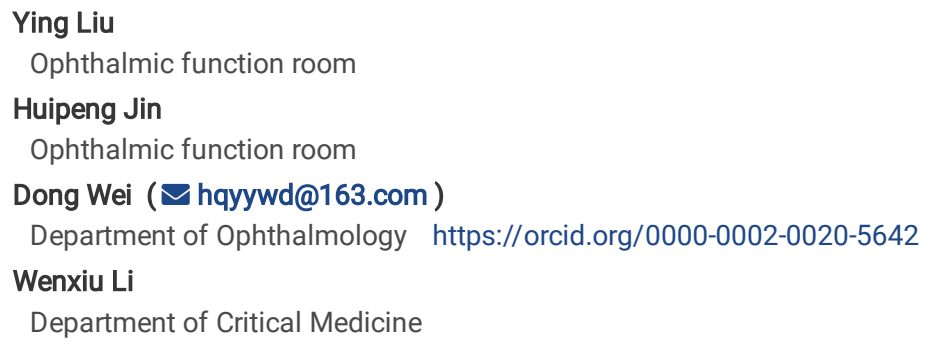




\section{Abstract}

Background The high-temperature requirement factor A1 (HTRA1) gene at the 10q26 locus has been associated with age-related macular degenerative (AMD) risk, with the significantly associated polymorphism being (rs11200638, -625G/A), however, above association is not consistent. We investigated an updated meta-analysis to evaluate the association between rs 11200638 polymorphism and AMD risk thoroughly addressing this issue.

Methods An identification was covered with the Pubmed and Chinese Wanfang databases through 27th Jan, 2020. Odds ratios (OR) and 95\% confidence intervals $(\mathrm{Cl})$ were used to assess the strength of associations. After a thorough and meticulous search, 35 different articles (33 case-control studies with HWE, 22 case-control studies about wet/dry AMD) were retrieved.

Results Individuals carrying A-allele or AA genotype may have an increased risk to be AMD disease. For example, there has a significantly increased relationship between rs11200638 polymorphism and AMD both for Asians (OR: 2.50, 95\%Cl: 2.22-2.80 for A-allele vs. G-allele) and Caucasians (OR: 2.11, 95\%Cl: 1.43-3.13 for A-allele vs. G-allele). Moreover, a similar trend in the source of control subgroup was detected. To classify the type of AMD, increased association was also observed in both wet (OR: 3.40, 95\% Cl: 2.90-3.99 for dominant model) and dry (OR: 2.08, 95\%Cl: 1.24-3.48 for dominant model) AMD. Finally, based on the different genotyping methods, increased relationships were identified by sequencing, TaqMan, PCR-RFLP.

Conclusions Our present meta-analysis suggests that the HTRA1 rs11200638 polymorphism are potentially associated with the risk of AMD development, especially about individuals carrying A-allele or AA genotype, who may be as identified targets to detect and intervene in advance. Further studies using larger sample sizes and including information about gene-environment interactions should be conducted to elucidate.

\section{Introduction}

Age-related macular degeneration (AMD) is the leading cause of vision loss in the elderly people in developed countries [1,2]. The number of individuals affected by AMD may be estimated to reach 17.8 million by 2050 [3]. The visual loss of AMD attributes to dead or non-functional photoreceptors and the underlying retinal pigment epithelium (RPE) [4]. Clinically, AMD is divided into two forms: The early stages, dry (atrophic, non-exudative) that can progress to geographic atrophy (GA) and the late stages, wet (exudative) AMD characterized by choroidal neovascularization $(\mathrm{CNV})[5,6]$.

Age, ethnicity, family history, smoking and sun exposure are common risk factors [7, 8], another important factor for AMD etiology is the genetic predisposition [9]. A genome-wide association study (GWAS) showed a clearer view about significant links between AMD risk and genetic variations in 2005, suggesting AMD is a polygenic disease [10], which triggered numerous studies involving the genetic associations of AMD in the following 15 years [11-13]. So far, AMRS2 rs10490924 polymorphism, SNPs from complement factor $\mathrm{H}, \mathrm{C} 2 / \mathrm{CFB}$, complement component C3, APOE haplotypes have been confirmed as being associated with susceptibility of AMD [14-18].

It is well known that vascular endothelial growth factor (VEGF) is involved in wet AMD development because that the formation of angiogenesis and vascular permeability can lead to fluid leakage across the blood vessels, and visual loss in the final [19]. Anti-VEGF agents such as ranibizumab and bevacizumab have been widely applied in the clinic $[20,21]$, in addition, have been proved to effectively slow the progress of CNV, however, heterogeneity was observed among patients in terms of the invalid samples and who have shorter duration of treatment [22]. It was hypothesized that genetic factors may participate in this period of this heterogeneous response, such as the variants of CHF, VEGFA, ARMS2 and high-temperature requirement factor A1 (HTRA1) genes [23-26].

HTRA1 encodes a member of the trypsin family of serine proteases and regulates the availability of insulin-like growth factors (IGFs) by cleaving IGF-binding proteins and transforming growth factor- $\beta$ (TGF- $\beta$ ), which have been suggested to be a regulator of cell growth, angiogenesis and extracellular matrix deposition. In addition, the inhibition of TGF- $\beta$ may lead to the overexpression of HTRA1 gene in wet AMD [27] (https://www.ncbi.nlm.nih.gov/gene/5654).

One of common polymorphisms in HTRA1 gene is rs11200638 (wide allele $\mathrm{G}$ to mutation allele A) [28]. Dewan et al. reported that the risk allele (A-allele) of the HTRA1 gene can influence the overexpression of its protein and then possible affect the integrity of Bruch's membrane and stimulate the progression of CNV stage [29].

In view of the foregoing, we realized that the important role of HTRA1 gene and its common rs11200638 polymorphism, we used the meta-analysis method to perform comprehensive conclusions including 28 different publications (33 case-control studies) [26, 30-57].

\section{Methods}

\section{Search Strategy}

We searched relative studies from PubMed and Wanfang databases before 27th Jan, 2020. The keywords were "age-related macular degeneration," "AMD," "polymorphism or variant," and "HTRA1 or high-temperature requirement factor A1." With these terms, a total of 35 different articles were included from above databases based on our inclusion criteria. Stages of AMD were assigned based on the classification of the Age-Related Eye Disease Study (AREDS) [58]. 
Included studies were according with (i) the correlation between AMD risk and HTRA1 gene rs11200638 polymorphism; (ii) case-control studies, and (iii) sufficient numbers of each genotypes (AA, AG, and GG) in case and control groups. Studies were excluded if they (i) included no control information; (ii) didn't contain genotype frequency data, and (iii) were duplicated studies with some other papers.

\section{Data Extraction}

Two authors (Ying Liu and Dong Wei) independently screened all papers that according with the selection criteria. These data included the first author's last name, publication year, country of origin, ethnicity, Hardy-Weinberg equilibrium (HWE) of control group, genotyping method and AMD disease types (dry and wet AMD). Ethnicity was categorized as Caucasian or Asian. The control subgroups were classified to population-based (PB) and hospital-based (HB).

\section{Statistical Analysis}

Based on the genotype frequencies for cases and controls, odds ratios (OR) with 95\% confidence intervals (Cl) were used to measure the strengths of associations. The statistical significance of the OR was determined with the $Z$ test [59]. The heterogeneity assumption among studies was evaluated using a $\chi^{2}$-square-based $Q$ test. If $P$-value $>0.10$ for the $Q$ test was indicated, a lack of heterogeneity among studies, other words, Mantel-Haenszel (fixed-effects model) was chosen, otherwise, the DerSimonian-Laird (random-effects model) was applied [60, 61]. We investigated the correlation between rs11200638 polymorphism and $A M D$ risk by testing whole five genetic models: $A$ versus $G, A G$ versus $G G, A A+A G$ versus $G G, A A$ versus $G G$ and $A A$ versus $A G+G G$. $A$ sensitivity analysis was performed by omitting studies, one after another, to assess the stability of results. The departure of frequencies of the rs 11200638 polymorphism from expectation under HWE was assessed by the Pearson's $\chi^{2}$ test, $P<0.05$ was considered significant [62]. The funnel plot was evaluated by Begg's test, and the publication bias was evaluated by Egger's test, whose $P$-value $<0.05$ was considered significant [63]. All statistical tests for this metaanalysis were performed using version 10.0 Stata software (StataCorp LP, College Station, TX, USA). The power and sample size analysis of our metaanalysis was calculated by a program called PS: Power and Sample Size

Calculation(http://biostat.mc.vanderbilt.edu/wiki/Main/PowerSampleSize\#Windows)

\section{Network of gene-interaction of HTRA1 gene}

To more complete understanding of the role of HTRA1 in AMD, the network of gene-gene interactions for HTRA1 gene was utilized through String online server (http://string-db.org/) [64].

\section{Results}

\section{Study searching and their basic information}

Using various combinations of key terms, a total of 262 article titles were garnered by a document search using the PubMed (222 titles) and Wanfang (40 titles) databases. As shown in Figure 1, 178 articles were excluded after screening the Abstract sections of the manuscripts. The full texts were then evaluated, and 49 additional articles were excluded due to duplication (7), meta-analysis or systematic analysis (26), clinical trial (10), randomized controlled trial (6). Finally, 35 different articles [26, 30-57, 65-69] were included in our meta-analysis, including 38 case-control studies about HTRA1 gene rs11200638 polymorphism and AMD risk (Table 1) and 27 case-control studies about HTRA1 gene rs11200638 polymorphism and wet or dry AMD risk (Table 2). Five case-control studies [65-69] were not consistent with HWE in control groups. To make our analysis to more strict, we deleted above five studies, so there were about 33 case-control studies (8101 cases and 7215 controls) for the whole AMD [26, 30-57], and 22 case-control studies for wet or dry (3938 cases and 4427 controls) studies [26, 30, 31, 33, 34, 40, 41, 43, 44, 46-48, 51, 53-56]. The frequency of the A allele from case group was found to be higher in control individuals (54.2\% vs. 36.5\%) (Figure 2). There were 19 case-control studies of Asian population, and 14 from Caucasian population; source of control in 22 case-control studies were from HB, and 11 were from PB; 17 case-control studies were about wet AMD disease, and 5 were about dry disease. Finally, we checked the Minor Allele Frequency (MAF) reported for the five main worldwide populations in the 1000 Genomes Browser (https://www.ncbi.nlm.nih.gov/snp/rs11200638): Global (0.290); East Asian (EAS=0.411); European (EUR=0.194); African (AFR=0.257); American $(A M R=0.250)$; and South Asian (SAS=0.340) (Figure 3). The genotyping methods included polymerase chain reaction-restrictive fragment length polymorphism and matrix-assisted laser desorption/ionization time-of-flight, sequencing, real-time PCR, and TaqMan.

\section{Quantitative Synthesis}

Total analysis

Results of the overall meta-analysis were suggestive of increasing associations between this polymorphism and AMD susceptibility in all five genetic models (for example: AA vs. GG: OR $=4.26,95 \mathrm{Cl} \%=3.19-6.70, P<0.001$ ) (Table 3 ). In order to make this study more convincing and reliable, we detected five studies, which were not according with HWE, finally, we tested the 32 case-control studies. Also significantly increasing correlations were observed in whole genetic models (for example: A-allele vs. G-allele: $\mathrm{OR}=2.36,95 \% \mathrm{Cl}=1.98-2.81, P<0.001 ; \mathrm{AA}+\mathrm{AG}$ vs. $\mathrm{GG}: \mathrm{OR}=2.53,95 \% \mathrm{Cl}=2.04-3.14, P<0.001$ ) (Figure 4) (Table 3). 
Subgroup analysis

Coming up, we all know that the frequency of A-allele in different races was not the same, so we tried to analysis the relationships by ethnicity subgroups in further, which indicated an incremental statistically association between this polymorphism and both in Asians ( $\mathrm{A}$-allele vs. G-allele: OR $=2.51,95 \% \mathrm{Cl}=$ 2.22-2.83, $P_{\text {heterogeneity }}<0.001, P<0.001$, Figure 4; AA vs. AG+GG: OR $\left.=3.69,95 \% \mathrm{Cl}=3.17-4.29, P_{\text {heterogeneity }}=0.013, P<0.001\right)$ and Caucasian populations (dominant model, $\mathrm{OR}=2.15,95 \% \mathrm{Cl}=1.46-3.17, P_{\text {heterogeneity }}<0.001$; heterozygote comparison, $\mathrm{OR}=1.82,95 \% \mathrm{Cl}=1.34-2.48, P_{\text {heterogeneity }}<0.001$; allelic comparison, $\mathrm{OR}=2.17,95 \% \mathrm{Cl}=1.53-3.10, P_{\text {heterogeneity }}<0.001, P<0.001$, Figure 4) (Table 3 ). In addition, regular analysis by source of control, also significantly increased risks were detected for this SNP both in PB and HB studies (AG vs. GG: OR $=1.70,95 \% \mathrm{Cl}=1.33-2.16, P_{\text {heterogeneity }}<0.001, P<0.001$ for HB; AG vs. GG: OR = 2.16, 95\% Cl = 1.84-2.53, $P_{\text {heterogeneity }}=0.021, P<0.001$ for PB) (Table 3) (Figure 5). AMD have different types and stages, the different of clinical presentation for dry and wet AMD is completely different, so we firmly believed that the correlations existed should be evaluated separately, significant positive associations were found both for dry (such as AA+AG vs. GG: OR $=2.73,95 \% \mathrm{Cl}=2.13-3.51, P$ heterogeneity $=0.498, P<0.001$,

Figure 6A) and wet AMD (for example in AA+AG vs. GG: OR $=3.40,95 \% \mathrm{Cl}=2.90-3.99, P_{\text {heterogeneity }}=0.073, P<0.001$, Figure 6B). Finally, different genotype methods were applied in included studies, we tried to in each method, whether associations may exist in our analysis, we found some positive results in

some methods (such as in AA vs. GG model: $\mathrm{OR}=7.00,95 \% \mathrm{Cl}=5.84-8.39, P_{\text {heterogeneity }}=0.677$ about sequencing, Figure $7 \mathrm{~A} ; \mathrm{OR}=7.52,95 \% \mathrm{Cl}=2.05-27.68$, $P_{\text {heterogeneity }}<0.001, P=0.002$ about TaqMan; $\mathrm{OR}=4.30,95 \% \mathrm{Cl}=2.51-7.35, P_{\text {heterogeneity }}=0.073$, Figure 7B) (Table 3).

\section{Bias Diagnosis for publication and sensitivity Analysis}

The publication bias was evaluated by both Begg's funnel plot and Egger's test. At beginning, the shape of the funnel plots seemed asymmetrical in allele comparison for rs11200638 by Begg's test, suggesting no publication bias was existed. Then, Egger's test was applied to provide statistical evidence of funnel plot symmetry. As a result, no obvious evidence of publication bias was observed (A-allele vs. G-allele, $t=0.89, P=0.38$ for Egger's test; $z=0.85, P=$ 0.396 for Begg's test, Supplementary Figure 1A,B)(Table 4).

To delete studies which may influence the power and stability of whole study, we applied the sensitive analysis, finally, no sensitive case-control studies were found (Supplementary Figure 2).

\section{Gene-gene network diagram and interaction of online website}

String online server indicated that HTRA1 gene interacts with numerous genes. The network of gene-gene interaction has been illustrated in Figure 8 .

\section{Discussion}

Because of the critical consequences about the visual loss caused by AMD, especially advanced AMD (atrophic/dry or neovascular/wet), it is necessary to study its etiology and mechanism, then to development early diagnostic methods and effective treatment. Nowadays, VEGF inhibitors are widely recognized as effective drugs in clinical application for CNV (wet AMD) [3, 70,71], instead of dry AMD. Therefore, to identify some novel detection markers and target drugs for different types of AMD is the current and future research focus on the direction. In the introduction section, we have enunciated the genetic factors may help us to search potential high-risk group about AMD, which can be prevented and treated in advance.

In our analysis, we chose the HTRA1 gene, which can regulate some kinds of growth factors. Rs11200638 polymorphism in HTRA1 is the most common SNP, which is getting noticed. However, Kanda et al. [35] demonstrated that there was no HTRA1 gene involved in related SNPs for AMD, and its rs11200638 polymorphism seemed to have no effect on the transcript. On the contrary, they found in the minus strand there had a putative mitochondrial protein LOC105378525 probably expressing in the retina, which could be a candidate gene. In fact, they showed that rs11200638 is in strong linkage disequilibrium with rs10490924, a nonsynonymous A69S alteration in the predicted protein named LOC105378525(LOC387715)/ARMS2. From their study, rs10490924 was a strong candidate SNP related to AMD risk instead of rs11200638. In addition, Bonyadi et al. [72] performed a meta-analysis about rs10490924, and revealed combined cigarette smoking and rs10490924 polymorphism may have significant association with AMD risk. We believed rs10490924 was a valuable SNP for AMD, nevertheless, conclusions based on a single study can not negate the potential functions for HTRA1 and its SNPs, which need more evidences and support from published and future researches.

Mori et al. first investigated the association between HTRA1 gene rs11200638 polymorphism and risk of AMD [47]. Other more following researchers duplicated their work in different populations and different types of AMD. However, results were confounding, even within same populations, though two published meta-analysis. It is well known that meta-analysis provides a means for effectively increasing the size of the sample by pooling data from individual correlation studies, thus enhancing the statistical power of the analysis to estimate genetic effects [73], which used this method to demonstrate statistically significant genetic associations.

Two previous meta-analysis [74, 75] about rs11200638 polymorphism and AMD have been reported, however, each study has its limitations. For example, Tang et al. just included fourteen case-control studies, two studies $[65,67]$ were not consistent with HWE, and Tuo et al. actually reported four-source casecontrol studies, which shouldn't be combined together [75]. Chen et al. also performed a meta-analysis in the same year including 14 case-control studies, similar limitations were existed [74]. After year of 2008, newly added studies have been published, and to perfect the above deficiencies, we performed an updated meta-analysis to come to a more convincing conclusion about HTRA1 gene rs11200638 polymorphism and AMD susceptibility.

To the best of our knowledge, this is the comprehensive and systematic meta-analysis exploring the associations between HTRA1 gene rs 11200638 polymorphism and AMD risk; it involved about 8101 AMD individuals and 7215 controls. Increased associations were found in the whole group, in Asian and 
Caucasian subgroups, source of control subgroup, and dry/wet sub-types of AMD, different genotyping methods (Sequencing, TaqMan, PCR-RFLP and MassARRAY MALDI-TOF), which means that A-allele or AA genotype is the risk factor for AMD, in other words, if individuals carry on this SNP from peripheral blood test, which may indicate that it is possible to increase the occurrence of AMD for them in present time or at some point in the future. Therefore, this polymorphism may be helpful in screening vulnerable populations for AMD in advance. In addition, the power of present study was 1.00 , which suggested our conclusions were stable and convincing.

In addition, the online analysis system-String was applied to predict potential and functional partners related to HTRA1, which can help us to better understand the value for detection and concern. Finally, ten genes were predicted. Among them, the highest score of association was ACAN (0.943), however, so far, no research has been reported between this gene and AMD and interaction between this gene and HTRA1. Future research should be payed attention to above information, which may be in favor of AMD early detection/prevention and intervention. In other partners, ARMS2 and CFH have been shown to associate with AMD. The ARMS2 and HTRA1 genes are located nearby on the 10q26 chromosome in a strong linkage disequilibrium. Significant association was observed that ARMS2 rs10490924 was related response to ranibizumab treatment among wet AMD subjects [68]. CFH gene T1277C polymorphism is strong associated with both wet and dry AMD and may be contribute to the inflammation in the pathogenesis of AMD [76]. As for the rest interaction genes (CLPP, CTRC, YME1L1, HSPD1, RPL34, CLPX and PLEKHG4) both had moderate score and no literature to support. It seems that above ten genes associated with HTRA1 came from text mining scores, which were derived from the co-occurrence of gene/protein names in related abstracts. In addition, it was important considered the occurrence of the LOC105378525 (LOC387715) and its polymorphism (A69S, rs10490924) as the main factor for AMD reported by Kanda et al (2007) [35], which should be added in the network of HTRA1 related genes. In a word, we should deep explore these partners of HTRA1 gene, and gene-gene interactions in the development of AMD in the next step.

There are some inherent limitations of our study should be declared. First, further studies should focus on Mixed and African populations, which was vacant in present analysis. Second, gene-gene and gene-environment interactions were not well analyzed. It is possible that specific environmental and lifestyle factors alter the associations between HTRA1 rs11200638 polymorphism and AMD, including age, diabetes, smoking, familial history, and hypertension. Third, vision is the most concerned-clinical indicator of AMD, future studies should include the value of the vision and analyze the relationships between rs11200638 polymorphism and the degree of visual impairment, which may help us to better detect disease progression.

\section{Conclusions}

In conclusion, our present meta-analysis suggests that HTRA1 rs11200638 polymorphism may be a risk factor for the susceptibility of AMD, larger and more comprehensive studies should be performed in the future

\section{Abbreviations}

AMD: age-related macular degeneration; GWAS: genome-wide association studies; HTRA1: high-temperature requirement factor A1; CNV: choroidal neovascularization; VEGF: vascular endothelial growth factor; RPE: retinal pigment epithelium; AREDS: Age-Related Eye Disease Study; SNP: single nucleotide polymorphism; HB: hospital-based; PB: population-based; SOC: source of control; PCR-RFLP: polymerase chain reaction followed by restriction fragment length polymorphism; MALDI-TOF: a chip-based matrix-assisted laser-desorption/ionization time-of-flight.

\section{Declarations}

\section{Acknowledgements}

Not applicable.

\section{Author contributions}

YL and HJ designed the study and drafted the manuscript; DW extracted, analyzed, interpreted the data, and collected the clinical data; DW and WL performed the targeted sequencing, analyzed and interpreted the data; DW and WL participated in the study coordination and revised the manuscript. All authors read and approved the final version of the manuscript.

\section{Funding}

This study was supported by Heilongjiang Health and Family Planning Commission Research Project (No. 2016-379). The funding body play no direct role in the design of the study, and collection, analysis, and interpretation of data, and in writing the manuscript.

\section{Availability of data and materials}

All the data generated in the present research is contained in this

manuscript. 
Ethics approval and consent to participate

Not applicable.

\section{Consent for publication}

Not applicable.

Competing interests

The authors declare that they have no competing interests.

Author details

${ }^{1}$ Ophthalmic function room, Hongqi Hospital Affiliated to Mudanjiang Medical College, Mudanjiang, 157000 , Heilongjiang Province, China. ${ }^{2}$ Department of Ophthalmology (three disease areas), Hongqi Hospital Affiliated to Mudanjiang Medical College, Mudanjiang, 157000هHeilongjiang Province, China.

${ }^{3}$ Department of Critical Medicine, Second People's Hospital of Mudanjiang, 157000هHeilongjiang Province, China

\section{References}

1. Klein BE, Klein R: Forecasting agerelated macular degeneration through 2050. Jama 2009, 301(20):2152-2153.

2. Klein R, Chou CF, Klein BE, Zhang X, Meuer SM, Saaddine JB: Prevalence of age-related macular degeneration in the US population. Archives of ophthalmology (Chicago, III : 1960) 2011, 129(1):75-80.

3. Khanna S, Komati R, Eichenbaum DA, Hariprasad I, Ciulla TA, Hariprasad SM: Current and upcoming anti-VEGF therapies and dosing strategies for the treatment of neovascular AMD: a comparative review. BMJ open ophthalmology 2019, 4(1):e000398.

4. Blasiak J: Senescence in the pathogenesis of age-related macular degeneration. Cellular and molecular life sciences : CMLS2020.

5. Rao P, Lum F, Wood K, Salman C, Burugapalli B, Hall R, Singh S, Parke DW, 2nd, Williams GA: Real-World Vision in Age-Related Macular Degeneration Patients Treated with Single Anti-VEGF Drug Type for 1 Year in the IRIS Registry. Ophthalmology 2018, 125(4):522-528.

6. Cukras C, Fine SL: Classification and grading system for age-related macular degeneration. International ophthalmology clinics 2007, 47(1):51-63.

7. Chakravarthy U, Wong TY, Fletcher A, Piault E, Evans C, Zlateva G, Buggage R, Pleil A, Mitchell P: Clinical risk factors for age-related macular degeneration: a systematic review and meta-analysis. BMC ophthalmology 2010, 10:31.

8. Jager RD, Mieler WF, Miller JW: Agerelated macular degeneration. The New England journal of medicine 2008, 358(24):2606-2617.

9. Shahid H, Khan JC, Cipriani V, Sepp T, Matharu BK, Bunce C, Harding SP, Clayton DG, Moore AT, Yates JR: Age-related macular degeneration: the importance of family history as a risk factor. The British journal of ophthalmology 2012, 96(3):427-431.

10. Klein RJ, Zeiss C, Chew EY, Tsai JY, Sackler RS, Haynes C, Henning AK, SanGiovanni JP, Mane SM, Mayne ST et al: Complement factor H polymorphism in age-related macular degeneration. Science (New York, NY) 2005, 308(5720):385-389.

11. Arakawa S, Takahashi A, Ashikawa K, Hosono N, Aoi T, Yasuda M, Oshima Y, Yoshida S, Enaida H, Tsuchihashi T et al: Genome-wide association study identifies two susceptibility loci for exudative age-related macular degeneration in the Japanese population. Nature genetics 2011, 43(10):1001-1004.

12. Fritsche LG, Fariss RN, Stambolian D, Abecasis GR, Curcio CA, Swaroop A: Age-related macular degeneration: genetics and biology coming together. Annual review of genomics and human genetics 2014, 15:151-171.

13. Neale BM, Fagerness J, Reynolds R, Sobrin L, Parker M, Raychaudhuri S, Tan PL, Oh EC, Merriam JE, Souied E et al: Genome-wide association study of advanced age-related macular degeneration identifies a role of the hepatic lipase gene (LIPC). Proceedings of the National Academy of Sciences of the United States of America 2010, 107(16):7395-7400.

14. Black JR, Clark SJ: Age-related macular degeneration: genome-wide association studies to translation. Genetics in medicine : official journal of the American College of Medical Genetics 2016, 18(4):283-289.

15. Duvvari MR, Paun CC, Buitendijk GH, Saksens NT, Volokhina EB, Ristau T, Schoenmaker-Koller FE, van de Ven JP, Groenewoud JM, van den Heuvel LP et al: Analysis of rare variants in the $\mathrm{C3}$ gene in patients with age-related macular degeneration. PloS one 2014, 9(4):e94165.

16. Fritsche LG, Chen W, Schu M, Yaspan BL, Yu Y, Thorleifsson G, Zack DJ, Arakawa S, Cipriani V, Ripke S et al: Seven new loci associated with age-related macular degeneration. Nature genetics 2013, 45(4):433-439, 439e431-432.

17. Lu F, Liu S, Hao Q, Liu L, Zhang J, Chen X, Hu W, Huang P: Association Between Complement Factor C2/C3/CFB/CFH Polymorphisms and Age-Related Macular Degeneration: A Meta-Analysis. Genetic testing and molecular biomarkers 2018, 22(9):526-540. 
18. Xiying M, Wenbo W, Wangyi F, Qinghuai L: Association of Apolipoprotein E Polymorphisms with Age-related Macular Degeneration Subtypes: An Updated Systematic Review and Meta-analysis. Archives of medical research 2017, 48(4):370-377.

19. Lim LS, Mitchell P, Seddon JM, Holz FG, Wong TY: Age-related macular degeneration. Lancet (London, England) 2012, 379(9827):1728-1738.

20. Moja L, Lucenteforte E, Kwag KH, Bertele V, Campomori A, Chakravarthy U, D'Amico R, Dickersin K, Kodjikian L, Lindsley K et al: Systemic safety of bevacizumab versus ranibizumab for neovascular age-related macular degeneration. The Cochrane database of systematic reviews 2014(9):Cd011230.

21. Solomon SD, Lindsley K, Vedula SS, Krzystolik MG, Hawkins BS: Anti-vascular endothelial growth factor for neovascular age-related macular degeneration. The Cochrane database of systematic reviews 2014(8):Cd005139.

22. Ba J, Peng RS, Xu D, Li YH, Shi H, Wang Q, Yu J: Intravitreal anti-VEGF injections for treating wet age-related macular degeneration: a systematic review and meta-analysis. Drug design, development and therapy 2015, 9:5397-5405.

23. Kloeckener-Gruissem B, Barthelmes D, Labs S, Schindler C, Kurz-Levin M, Michels S, Fleischhauer J, Berger W, Sutter F, Menghini M: Genetic association with response to intravitreal ranibizumab in patients with neovascular AMD. Investigative ophthalmology \& visual science 2011, 52(7):4694-4702.

24. Park UC, Shin JY, McCarthy LC, Kim SJ, Park JH, Chung H, Yu HG: Pharmacogenetic associations with long-term response to anti-vascular endothelial growth factor treatment in neovascular AMD patients. Molecular vision 2014, 20:1680-1694.

25. Ratnapriya R, Chew EY: Age-related macular degeneration-clinical review and genetics update. Clinical genetics 2013, 84(2):160-166.

26. Xu Y, Guan N, Xu J, Yang X, Ma K, Zhou H, Zhang F, Snellingen T, Jiao Y, Liu X et al: Association of CFH, LOC387715, and HTRA1 polymorphisms with exudative age-related macular degeneration in a northern Chinese population. Molecular vision 2008, 14:1373-1381.

27. Tosi GM, Caldi E, Neri G, Nuti E, Marigliani D, Baiocchi S, Traversi C, Cevenini G, Tarantello A, Fusco F et al: HTRA1 and TGF-beta1 Concentrations in the Aqueous Humor of Patients With Neovascular Age-Related Macular Degeneration. Investigative ophthalmology \& visual science 2017, 58(1):162-167.

28. Yang Z, Camp NJ, Sun H, Tong Z, Gibbs D, Cameron DJ, Chen H, Zhao Y, Pearson E, Li X et al: A variant of the HTRA1 gene increases susceptibility to age-related macular degeneration. Science (New York, NY) 2006, 314(5801):992-993.

29. Dewan A, Liu M, Hartman S, Zhang SS, Liu DT, Zhao C, Tam PO, Chan WM, Lam DS, Snyder M et al: HTRA1 promoter polymorphism in wet age-related macular degeneration. Science (New York, NY) 2006, 314(5801):989-992.

30. Askari M, Nikpoor AR, Gorjipour F, Mazidi M, Sanati MH, Aryan H, Irani A, Ghasemi Falavarjani K, Nazari H, Mousavizadeh K: Association of Htra1 gene polymorphisms with the risk of developing AMD in Iranian population. Reports of biochemistry \& molecular biology 2015, 4(1):43-49.

31. Chan CC, Shen D, Zhou M, Ross RJ, Ding X, Zhang K, Green WR, Tuo J: Human HtrA1 in the archived eyes with age-related macular degeneration. Transactions of the American Ophthalmological Society 2007, 105:92-97; discussion 97-98.

32. Chen JH, Yang Y, Zheng Y, Qiu M, Xie M, Lin W, Zhang M, Pang CP, Chen H: No association of age-related maculopathy susceptibility protein 2/HtrA serine peptidase 1 or complement factor $\mathrm{H}$ polymorphisms with early agerelated maculopathy in a Chinese cohort. Molecular vision 2013, 19:944-954.

33. Cheng Y, Huang L, Li X, Zhou P, Zeng W, Zhang C: Genetic and functional dissection of ARMS2 in age-related macular degeneration and polypoidal choroidal vasculopathy. PloS one 2013, 8(1):e53665.

34. Chu J, Zhou CC, Lu N, Zhang X, Dong FT: Genetic variants in three genes and smoking show strong associations with susceptibility to exudative agerelated macular degeneration in a Chinese population. Chinese medical journal 2008, 121(24):2525-2533.

35. Kanda A, Chen W, Othman M, Branham KE, Brooks M, Khanna R, He S, Lyons R, Abecasis GR, Swaroop A: A variant of mitochondrial protein LOC387715/ARMS2, not HTRA1, is strongly associated with age-related macular degeneration. Proceedings of the National Academy of Sciences of the United States of America 2007, 104(41):16227-16232.

36. Kaur I, Cantsilieris S, Katta S, Richardson AJ, Schache M, Pappuru RR, Narayanan R, Mathai A, Majji AB, Tindill N et al: Association of the del443ins54 at the ARMS2 locus in Indian and Australian cohorts with age-related macular degeneration. Molecular vision 2013, 19:822-828.

37. Kaur I, Katta S, Hussain A, Hussain N, Mathai A, Narayanan R, Hussain A, Reddy RK, Majji AB, Das T et al: Variants in the 10q26 gene cluster (LOC387715 and HTRA1) exhibit enhanced risk of age-related macular degeneration along with CFH in Indian patients. Investigative ophthalmology \& visual science 2008, 49(5):1771-1776.

38. Kondo N, Honda S, Ishibashi K, Tsukahara Y, Negi A: LOC387715/HTRA1 variants in polypoidal choroidal vasculopathy and age-related macular degeneration in a Japanese population. American journal of ophthalmology 2007, 144(4):608-612.

39. Lana TP, da Silva Costa SM, Ananina G, Hirata FE, Rim PHH, Medina FM, de Vasconcellos JPC, de Melo MB: Association of HTRA1 rs11200638 with age-related macular degeneration (AMD) in Brazilian patients. Ophthalmic genetics 2018, 39(1):46-50.

40. Lee SJ, Kim NR, Chin HS: LOC387715/HTRA1 polymorphisms, smoking and combined effects on exudative age-related macular degeneration in a Korean population. Clinical \& experimental ophthalmology 2010, 38(7):698-704.

41. Leveziel N, Souied EH, Richard F, Barbu V, Zourdani A, Morineau G, Zerbib J, Coscas G, Soubrane G, Benlian P: PLEKHA1-LOC387715-HTRA1 polymorphisms and exudative age-related macular degeneration in the French population. Molecular vision 2007, 13:2153-2159.

42. Li WJ, Sheng XL, Zhuang WJ, Li HP: Associations of SNPs in ARMS2/HTRA1 with age-related macular degeneration. Ningxia Medical University Thesis for Master's Degree 2015.

43. Liang X, Cui L, Gu H, Zhou HY, Xu J, Liu NP: Interaction of susceptibility genes in patients with exudative age-related macular degeneration. Chin J Ophthalmol 2012, 48(3):241-245.

44. Lin JM, Wan L, Tsai YY, Lin HJ, Tsai Y, Lee CC, Tsai CH, Tsai FJ, Tseng SH: HTRA1 polymorphism in dry and wet age-related macular degeneration. Retina (Philadelphia, Pa) 2008, 28(2):309-313 
45. Losonczy G, Fekete A, Voko Z, Takacs L, Kaldi I, Ajzner E, Kasza M, Vajas A, Berta A, Balogh I: Analysis of complement factor H Y402H, LOC387715, HTRA1 polymorphisms and ApoE alleles with susceptibility to age-related macular degeneration in Hungarian patients. Acta ophthalmologica 2011, 89(3):255-262.

46. Matuskova V, Zeman T, Ewerlingova L, Hlinomazova Z, Soucek J, Vlkova E, Goswami N, Balcar VJ, Sery O: An association of neovascular age-related macular degeneration with polymorphisms of CFH, ARMS2, HTRA1 and C3 genes in Czech population. Acta ophthalmologica 2020.

47. Mori K, Horie-Inoue K, Kohda M, Kawasaki I, Gehlbach PL, Awata T, Yoneya S, Okazaki Y, Inoue S: Association of the HTRA1 gene variant with agerelated macular degeneration in the Japanese population. Journal of human genetics 2007, 52(7):636-641.

48. Ng TK, Liang XY, Lai TY, Ma L, Tam PO, Wang JX, Chen LJ, Chen H, Pang CP: HTRA1 promoter variant differentiates polypoidal choroidal vasculopathy from exudative age-related macular degeneration. Scientific reports 2016, 6:28639.

49. Tian J, Qin X, Fang K, Chen Q, Hou J, Li J, Yu W, Chen D, Hu Y, Li X: Association of genetic polymorphisms with response to bevacizumab for neovascular age-related macular degeneration in the Chinese population. Pharmacogenomics 2012, 13(7):779-787.

50. Tuo J, Ross RJ, Reed GF, Yan Q, Wang JJ, Bojanowski CM, Chew EY, Feng X, Olsen TW, Ferris FL et al: The HtrA1 promotor polymorphism, smoking, and age-related macular degeneration in multiple case-control samples. Ophthalmology 2008, 115(11):1891-1898.

51. Weger M, Renner W, Steinbrugger I, Kofer K, Wedrich A, Groselj-Strele A, El-Shabrawi Y, Schmut O, Haas A: Association of the HTRA1 -625G>A promoter gene polymorphism with exudative age-related macular degeneration in a Central European population. Molecular vision 2007, 13:1274-1279.

52. Yang N, Xing J, Shao Y, Zhu Z, Ba YY, Wei W: Relationship between HTRA1 polymorphism and genetic susceptibility of wet age-related macular degeneration in Han population. Guoji Yanke Zazhi 2018, 18(5):815-818.

53. Zeng JX, Tang LS, Zhang K: Assessing susceptibility to age-related macular gegeneration with genetic makers and environment factors. Doctoral Dissertation of Zhongnan University 2011.

54. Tam PO, Ng TK, Liu DT, Chan WM, Chiang SW, Chen LJ, DeWan A, Hoh J, Lam DS, Pang CP: HTRA1 variants in exudative age-related macular degeneration and interactions with smoking and CFH. Investigative ophthalmology \& visual science 2008, 49(6):2357-2365.

55. Jiang H, Qu Y, Dang G, Zhang X, Yin N, Zhang Y, Bi H, Pan X, Xu X, Zhou F et al: Analyses of single nucleotide polymorphisms and haplotype linkage of LOC387715 and the HTRA1 gene in exudative age-related macular degeneration in a Chinese cohort. Retina (Philadelphia, Pa) 2009, 29(7):974-979.

56. Ruamviboonsuk P, Tadarati M, Singhanetr P, Wattanapokayakit S, Kunhapan P, Wanitchanon T, Wichukchinda N, Mushiroda T, Akiyama M, Momozawa Y et al: Genome-wide association study of neovascular age-related macular degeneration in the Thai population. Journal of human genetics 2017 , 62(11):957-962.

57. Fritsche LG, Loenhardt T, Janssen A, Fisher SA, Rivera A, Keilhauer CN, Weber BH: Age-related macular degeneration is associated with an unstable ARMS2 (LOC387715) mRNA. Nature genetics 2008, 40(7):892-896.

58. Davis MD, Gangnon RE, Lee LY, Hubbard LD, Klein BE, Klein R, Ferris FL, Bressler SB, Milton RC: The Age-Related Eye Disease Study severity scale for age-related macular degeneration: AREDS Report No. 17. Archives of ophthalmology (Chicago, III : 1960) 2005, 123(11):1484-1498.

59. Higgins JP, Thompson SG: Quantifying heterogeneity in a meta-analysis. Statistics in medicine 2002, 21(11):1539-1558.

60. DerSimonian R, Laird N: Meta-analysis in clinical trials. Controlled clinical trials 1986, 7(3):177-188.

61. Mantel N, Haenszel W: Statistical aspects of the analysis of data from retrospective studies of disease. Journal of the National Cancer Institute 1959, 22(4):719-748.

62. Napolioni V: The relevance of checking population allele frequencies and Hardy-Weinberg Equilibrium in genetic association studies: the case of SLC6A4 5-HTTLPR polymorphism in a Chinese Han Irritable Bowel Syndrome association study. Immunology letters 2014, 162(1 Pt A):276-278.

63. Hayashino Y, Noguchi Y, Fukui T: Systematic evaluation and comparison of statistical tests for publication bias. Journal of epidemiology 2005, 15(6):235-243.

64. Shao HB, Ren K, Gao SL, Zou JG, Mi YY, Zhang LF, Zuo L, Okada A, Yasui T: Human methionine synthase A2756G polymorphism increases susceptibility to prostate cancer. Aging 2018, 10(7):1776-1788.

65. Chen H, Yang Z, Gibbs D, Yang X, Hau V, Zhao P, Ma X, Zeng J, Luo L, Pearson E et al: Association of HTRA1 polymorphism and bilaterality in advanced age-related macular degeneration. Vision research 2008, 48(5):690-694.

66. Cruz-Gonzalez F, Cieza-Borrella C, Lopez Valverde G, Lorenzo-Perez R, Hernandez-Galilea E, Gonzalez-Sarmiento R: CFH (rs1410996), HTRA1 (rs112000638) and ARMS2 (rs10490923) gene polymorphisms are associated with AMD risk in Spanish patients. Ophthalmic genetics 2014, 35(2):6873.

67. Lu F, Hu J, Zhao P, Lin Y, Yang Y, Liu X, Fan Y, Chen B, Liao S, Du Q et al: HTRA1 variant increases risk to neovascular age-related macular degeneration in Chinese population. Vision research 2007, 47(24):3120-3123.

68. Mohamad NA, Ramachandran V, Mohd Isa H, Chan YM, Ngah NF, Ching SM, Hoo FK, Wan Sulaiman WA, Inche Mat LN, Mohamed MH: Association of HTRA1 and ARMS2 gene polymorphisms with response to intravitreal ranibizumab among neovascular age-related macular degenerative subjects. Human genomics 2019, 13(1):13.

69. Yang X, Hu J, Zhang J, Guan H: Polymorphisms in CFH, HTRA1 and CX3CR1 confer risk to exudative age-related macular degeneration in Han Chinese. The British journal of ophthalmology 2010, 94(9):1211-1214.

70. Amoaku WM, Chakravarthy U, Gale R, Gavin M, Ghanchi F, Gibson J, Harding S, Johnston RL, Kelly SP, Lotery A et al: Defining response to anti-VEGF therapies in neovascular AMD. Eye (London, England) 2015, 29(6):721-731. 
71. Cheung GCM, Lai TYY, Gomi F, Ruamviboonsuk P, Koh A, Lee WK: Anti-VEGF Therapy for Neovascular AMD and Polypoidal Choroidal Vasculopathy. Asia-Pacific journal of ophthalmology (Philadelphia, Pa) 2017, 6(6):527-534.

72. Jabbarpoor Bonyadi MH, Yaseri M, Bonyadi M, Soheilian M, Nikkhah H: Association of combined cigarette smoking and ARMS2/LOC387715 A69S polymorphisms with age-related macular degeneration: A meta-analysis. Ophthalmic genetics 2017, 38(4):308-313.

73. Munafo MR, Flint J: Meta-analysis of genetic association studies. Trends in genetics : TIG 2004, 20(9):439-444.

74. Chen W, Xu W, Tao Q, Liu J, Li X, Gan X, Hu H, Lu Y: Meta-analysis of the association of the HTRA1 polymorphisms with the risk of age-related macular degeneration. Experimental eye research 2009, 89(3):292-300.

75. Tang NP, Zhou B, Wang B, Yu RB: HTRA1 promoter polymorphism and risk of age-related macular degeneration: a meta-analysis. Annals of epidemiology 2009, 19(10):740-745.

76. Narayanan R, Butani V, Boyer DS, Atilano SR, Resende GP, Kim DS, Chakrabarti S, Kuppermann BD, Khatibi N, Chwa M et al: Complement factor H polymorphism in age-related macular degeneration. Ophthalmology 2007, 114(7):1327-1331.

\section{Supplementary Materials}

Supplementary Figure 1. A: Begg's funnel plot for publication bias test (A-allele vs. G-allele). Each point represents a separate study for the indicated association. Log [OR], natural logarithm of OR. Horizontal line, mean effect size. B: Egger's publication bias plot (A-allele vs. G-allele).

Supplementary Figure 2. Sensitivity analysis between HTRA1 gene rs11200638 polymorphism and AMD risk (A-allele vs. G-allele).

\section{Tables}

Table 1 Characteristics of included studies in HTRA1 rs11200638 polymorphism and AMD risk. 


\begin{tabular}{|c|c|c|c|c|c|c|c|c|c|c|c|c|c|c|c|}
\hline \multirow[t]{2}{*}{ Author } & \multirow[t]{2}{*}{ Year } & \multirow[t]{2}{*}{ Country } & \multirow[t]{2}{*}{ Ethnicity } & \multirow[t]{2}{*}{ type } & \multirow[t]{2}{*}{ Case } & \multirow[t]{2}{*}{ Control } & \multirow[t]{2}{*}{$\mathrm{SOC}$} & \multicolumn{3}{|l|}{ Cases } & \multicolumn{3}{|l|}{ Controls } & \multirow[t]{2}{*}{ HWE } & \multirow[t]{2}{*}{ Genotype } \\
\hline & & & & & & & & AA & AG & GG & AA & AG & GG & & \\
\hline Tian & 2012 & China & Asian & AMD & 532 & 468 & $\mathrm{HB}$ & 255 & 193 & 84 & 104 & 224 & 140 & 0.423 & Typer 4.0 software \\
\hline Ruamviboonsuk & 2017 & Thailand & Asian & wet & 377 & 1073 & PB & 125 & 164 & 88 & 146 & 490 & 437 & 0.643 & $\begin{array}{l}\text { InfiniumOmniExpressExome- } \\
8 \text { v1.3 platform }\end{array}$ \\
\hline Chu & 2008 & China & Asian & wet & 144 & 126 & HB & 76 & 52 & 16 & 31 & 69 & 26 & 0.276 & PCR-RFLP \\
\hline Losonczy & 2011 & Hungary & Caucasian & AMD & 103 & 95 & $\mathrm{HB}$ & 23 & 50 & 30 & 3 & 49 & 43 & 0.133 & PCR-RFLP \\
\hline Tuo & 2008 & USA & Caucasian & AMD & 142 & 132 & $\mathrm{~PB}$ & 33 & 60 & 49 & 7 & 51 & 74 & 0.638 & PCR-RFLP \\
\hline Tuo & 2008 & USA & Caucasian & AMD & 330 & 191 & $\mathrm{~PB}$ & 63 & 164 & 103 & 12 & 73 & 106 & 0.904 & PCR-RFLP \\
\hline Tuo & 2008 & USA & Caucasian & AMD & 272 & 555 & $\mathrm{~PB}$ & 15 & 122 & 135 & 20 & 186 & 349 & 0.431 & PCR-RFLP \\
\hline Tuo & 2008 & USA & Caucasian & AMD & 46 & 22 & $\mathrm{~PB}$ & 2 & 15 & 29 & 1 & 6 & 15 & 0.696 & PCR-RFLP \\
\hline Chan & 2007 & USA & Caucasian & AMD & 52 & 13 & $\mathrm{HB}$ & 14 & 27 & 11 & 0 & 8 & 5 & 0.109 & RT-PCR \\
\hline Kanda & 2007 & USA & Caucasian & AMD & 457 & 280 & HB & 172 & 183 & 102 & 179 & 90 & 11 & 0.94 & RT-PCR \\
\hline Cheng & 2013 & China & Asian & wet & 93 & 93 & HB & 52 & 30 & 11 & 21 & 42 & 30 & 0.395 & Sequencing \\
\hline Liang & 2012 & China & Asian & wet & 161 & 150 & $\mathrm{HB}$ & 61 & 83 & 17 & 30 & 72 & 48 & 0.751 & Sequencing \\
\hline Jiang & 2008 & China & Asian & wet & 159 & 140 & $\mathrm{HB}$ & 99 & 47 & 13 & 31 & 67 & 42 & 0.662 & Sequencing \\
\hline Lee & 2010 & Korea & Asian & wet & 137 & 187 & $\mathrm{HB}$ & 57 & 59 & 21 & 35 & 100 & 52 & 0.283 & Sequencing \\
\hline Lin & 2008 & $\begin{array}{l}\text { China- } \\
\text { Taiwan }\end{array}$ & Asian & AMD & 95 & 90 & $\mathrm{HB}$ & 53 & 33 & 9 & 19 & 47 & 24 & 0.651 & Sequencing \\
\hline Kaur & 2008 & India & Asian & AMD & 229 & 184 & $\mathrm{HB}$ & 90 & 89 & 50 & 21 & 85 & 78 & 0.765 & Sequencing \\
\hline $\mathrm{Xu}$ & 2007 & China & Asian & wet & 121 & 132 & $\mathrm{HB}$ & 56 & 52 & 13 & 24 & 64 & 44 & 0.931 & Sequencing \\
\hline Tam & 2008 & $\begin{array}{l}\text { China-Hong } \\
\text { Kong }\end{array}$ & Asian & wet & 163 & 183 & $\mathrm{HB}$ & 94 & 51 & 18 & 38 & 90 & 55 & 0.916 & Sequencing \\
\hline Mori & 2007 & Japan & Asian & AMD & 123 & 133 & $\mathrm{HB}$ & 45 & 52 & 26 & 22 & 57 & 54 & 0.298 & Sequencing \\
\hline Askari & 2015 & Iran & Asian & AMD & 120 & 120 & $\mathrm{HB}$ & 58 & 42 & 20 & 12 & 66 & 42 & 0.057 & Sequencing \\
\hline Lana & 2018 & Brazil & Caucasian & AMD & 204 & 166 & HB & 73 & 89 & 42 & 22 & 77 & 67 & 0.987 & Sequencing \\
\hline Kaur & 2013 & India & Asian & AMD & 198 & 145 & $\mathrm{~PB}$ & 84 & 70 & 44 & 17 & 67 & 61 & 0.829 & Sequencing \\
\hline $\mathrm{Ng}$ & 2016 & Hong Kong & Asian & wet & 194 & 183 & $\mathrm{~PB}$ & 109 & 63 & 22 & 38 & 90 & 55 & 0.916 & Sequencing \\
\hline Kaur & 2013 & India & Caucasian & AMD & 616 & 426 & $\mathrm{~PB}$ & 130 & 292 & 194 & 17 & 138 & 271 & 0.913 & Sequencing \\
\hline Chen & 2013 & China & Asian & AMD & 158 & 157 & HB & 28 & 74 & 56 & 21 & 77 & 59 & 0.599 & TaqMan \\
\hline Kondo & 2007 & Japan & Asian & AMD & 73 & 94 & $\mathrm{HB}$ & 29 & 39 & 5 & 16 & 40 & 38 & 0.334 & TaqMan \\
\hline Leveziel & 2007 & France & Caucasian & wet & 118 & 116 & $\mathrm{HB}$ & 32 & 57 & 29 & 5 & 41 & 70 & 0.743 & TaqMan \\
\hline Weger & 2007 & Austria & Caucasian & wet & 242 & 157 & $\mathrm{~PB}$ & 67 & 108 & 67 & 8 & 50 & 99 & 0.609 & TaqMan \\
\hline $\mathrm{Lu}$ & 2007 & China & Asian & wet & 90 & 106 & $\mathrm{HB}$ & 53 & 34 & 3 & 15 & 63 & 28 & $<0.05$ & PCR-RFLP \\
\hline Cruz-González & 2013 & Spain & Caucasian & AMD & 121 & 91 & $\mathrm{HB}$ & 29 & 60 & 32 & 61 & 21 & 9 & $<0.05$ & PCR-RFLP \\
\hline Mohamad & 2019 & Malaysia & Asian & wet & 145 & 145 & $\mathrm{HB}$ & 79 & 47 & 19 & 48 & 82 & 15 & $<0.05$ & PCR-RFLP \\
\hline Yang & 2010 & China & Asian & wet & 109 & 150 & HB & 31 & 45 & 33 & 30 & 50 & 70 & $<0.05$ & PCR-RFLP \\
\hline Chen & 2008 & USA & Caucasian & AMD & 776 & 294 & $\mathrm{HB}$ & 131 & 400 & 245 & 10 & 128 & 156 & $<0.05$ & Sequencing \\
\hline Zeng & 2011 & China & Caucasian & AMD & 1335 & 509 & PB & 244 & 641 & 450 & 21 & 181 & 307 & 0.374 & SNaPshot \\
\hline $\mathrm{Li}$ & 2015 & China & Asian & AMD & 146 & 145 & $\mathrm{HB}$ & 73 & 54 & 19 & 44 & 74 & 27 & 0.674 & MassARRAY MALDI-TOF \\
\hline Yang & 2018 & China & Asian & AMD & 201 & 201 & HB & 103 & 74 & 24 & 42 & 100 & 59 & 0.975 & MassARRAY MALDI-TOF \\
\hline Matuskova & 2020 & $\begin{array}{l}\text { Czech } \\
\text { Republic }\end{array}$ & Caucasian & wet & 307 & 191 & $\mathrm{HB}$ & 69 & 148 & 90 & 9 & 66 & 116 & 0.921 & SNaPshot Multiplex-System \\
\hline Fritsche & 2008 & Germany & Caucasian & AMD & 760 & 549 & $\mathrm{~PB}$ & 152 & 344 & 264 & 22 & 174 & 353 & 0.923 & Multiplex PCR \\
\hline
\end{tabular}

HB: hospital-based; PB: population-based; SOC; source of control; PCR-RFLP: polymerase chain reaction followed by restriction fragment length polymorphism; RT-PCR: real-time PCR; MALDI-TOF: polymerase chain reaction-matrix-assisted laser desorption/ionization time-of-flight; HWE: Hardy-Weinberg equilibrium of control group

Table 2 Characteristics of included studies in HTRA1 rs11200638 polymorphism and wet/dry AMD risk, respectively. 


\begin{tabular}{|c|c|c|c|c|c|c|c|c|c|c|c|c|c|c|c|}
\hline \multirow[t]{2}{*}{ Author } & \multirow[t]{2}{*}{ Year } & \multirow[t]{2}{*}{ Country } & \multirow[t]{2}{*}{ Ethnicity } & \multirow[t]{2}{*}{ type } & \multirow[t]{2}{*}{ Case } & \multirow[t]{2}{*}{ Control } & \multirow[t]{2}{*}{ SOC } & \multicolumn{3}{|l|}{ Cases } & \multicolumn{3}{|l|}{ Controls } & \multirow[t]{2}{*}{ HWE } & \multirow[t]{2}{*}{ Genotype } \\
\hline & & & & & & & & AA & AG & GG & AA & AG & GG & & \\
\hline Lin & 2008 & China-Taiwan & Asian & dry & 52 & 90 & HB & 28 & 19 & 5 & 19 & 47 & 24 & 0.651 & Sequencing \\
\hline Chan & 2007 & USA & Caucasian & dry & 18 & 13 & HB & 4 & 10 & 4 & 0 & 8 & 5 & 0.109 & RT-PCR \\
\hline Mori & 2007 & Japan & Asian & dry & 19 & 116 & HB & 4 & 7 & 8 & 5 & 41 & 70 & 0.743 & Sequencing \\
\hline Askari & 2015 & Iran & Asian & dry & 32 & 120 & HB & 11 & 12 & 9 & 12 & 66 & 42 & 0.576 & Sequencing \\
\hline Ruamviboonsuk & 2017 & Thailand & Asian & wet & 377 & 1073 & $\mathrm{~PB}$ & 125 & 164 & 88 & 146 & 490 & 437 & 0.643 & $\begin{array}{l}\text { InfiniumOmniExpressExome-8 } \\
\text { v1.3 platform }\end{array}$ \\
\hline Cheng & 2013 & China & Asian & wet & 93 & 93 & HB & 52 & 30 & 11 & 21 & 42 & 30 & 0.395 & Sequencing \\
\hline $\mathrm{Ng}$ & 2016 & Hong Kong & Asian & wet & 194 & 183 & $\mathrm{~PB}$ & 109 & 63 & 22 & 38 & 90 & 55 & 0.915 & Sequencing \\
\hline Liang & 2012 & China & Asian & wet & 161 & 150 & HB & 61 & 83 & 17 & 30 & 72 & 48 & 0.75 & Sequencing \\
\hline Chu & 2008 & China & Asian & wet & 144 & 126 & HB & 76 & 52 & 16 & 31 & 69 & 26 & 0.276 & PCR-RFLP \\
\hline Jiang & 2008 & China & Asian & wet & 159 & 140 & HB & 99 & 47 & 13 & 31 & 67 & 42 & 0.662 & Sequencing \\
\hline Lee & 2010 & Korea & Asian & wet & 137 & 187 & HB & 57 & 59 & 21 & 35 & 100 & 52 & 0.283 & Sequencing \\
\hline Lin & 2008 & China-Taiwan & Asian & wet & 43 & 90 & HB & 25 & 14 & 4 & 19 & 47 & 24 & 0.651 & Sequencing \\
\hline $\mathrm{Xu}$ & 2007 & China & Asian & wet & 121 & 132 & HB & 56 & 52 & 13 & 24 & 64 & 44 & 0.931 & Sequencing \\
\hline Tam & 2008 & $\begin{array}{l}\text { China-Hong } \\
\text { Kong }\end{array}$ & Asian & wet & 163 & 183 & HB & 94 & 51 & 18 & 38 & 90 & 55 & 0.916 & Sequencing \\
\hline Chan & 2007 & USA & Caucasian & wet & 31 & 13 & HB & 8 & 16 & 7 & 0 & 8 & 5 & 0.109 & RT-PCR \\
\hline Leveziel & 2007 & France & Caucasian & wet & 118 & 116 & HB & 32 & 57 & 29 & 5 & 41 & 70 & 0.743 & TaqMan \\
\hline Mori & 2007 & Japan & Asian & wet & 104 & 116 & HB & 41 & 45 & 18 & 5 & 41 & 70 & 0.743 & Sequencing \\
\hline Askari & 2015 & Iran & Asian & wet & 88 & 120 & HB & 47 & 30 & 11 & 12 & 66 & 42 & 0.576 & Sequencing \\
\hline Weger & 2007 & Austria & Caucasian & wet & 242 & 157 & $\mathrm{~PB}$ & 67 & 108 & 67 & 8 & 50 & 99 & 0.609 & TaqMan \\
\hline $\mathrm{Lu}$ & 2007 & China & Asian & wet & 90 & 106 & HB & 53 & 34 & 3 & 15 & 63 & 28 & $<0.05$ & PCR-RFLP \\
\hline Mohamad & 2019 & Malaysia & Asian & wet & 145 & 145 & $\mathrm{HB}$ & 79 & 47 & 19 & 48 & 82 & 15 & $<0.05$ & PCR-RFLP \\
\hline Yang & 2010 & China & Asian & wet & 109 & 150 & HB & 31 & 45 & 33 & 30 & 50 & 70 & $<0.05$ & PCR-RFLP \\
\hline Chen & 2008 & USA & Caucasian & wet & 470 & 294 & HB & 76 & 245 & 149 & 10 & 128 & 156 & $<0.05$ & Sequencing \\
\hline Chen & 2008 & USA & Caucasian & dry & 306 & 294 & HB & 55 & 155 & 96 & 10 & 128 & 156 & $<0.05$ & Sequencing \\
\hline Zeng & 2011 & China & Caucasian & dry & 341 & 509 & PB & 60 & 166 & 115 & 21 & 181 & 307 & 0.374 & SNaPshot \\
\hline Zeng & 2011 & China & Caucasian & wet & 994 & 509 & PB & 184 & 475 & 335 & 21 & 181 & 307 & 0.374 & SNaPshot \\
\hline Matuskova & 2020 & Czech Republic & Caucasian & wet & 307 & 191 & $\mathrm{HB}$ & 69 & 148 & 90 & 9 & 66 & 116 & 0.921 & SNaPshot Multiplex-System \\
\hline
\end{tabular}

Table 3 Results of the meta-analysis on HTRA1 rs11200638 polymorphism and AMD risk in total and types of subgroups.

\begin{tabular}{|c|c|c|c|c|c|c|c|}
\hline \multirow[t]{2}{*}{ Variables } & \multirow[t]{2}{*}{$\mathbf{N}$} & \multirow{2}{*}{$\begin{array}{l}\text { Case/ } \\
\text { Control }\end{array}$} & A-allele vs. G-allele & AG vs. GG & $\mathrm{AA}+\mathrm{AG}$ vs. GG & AA vs. GG & AA vs. AG+GG \\
\hline & & & $\begin{array}{lll}\text { OR(95\%CI) } & P_{\mathrm{h}} & P\end{array}$ & $\begin{array}{lll}\text { OR(95\%CI) } & P_{\mathrm{h}} & P\end{array}$ & $\begin{array}{lll}\text { OR(95\%CI) } & P_{\mathrm{h}} & P \\
\end{array}$ & OR(95\%CI) & OR(95\%CI) \\
\hline Total & 38 & $8582 / 7452$ & $\begin{array}{l}2.18(1.79-2.67) 0.000 \\
0.000\end{array}$ & $\begin{array}{l}1.73(1.45-2.05) 0.000 \\
0.000\end{array}$ & $\begin{array}{l}2.36(1.91-2.91) 0.000 \\
0.000\end{array}$ & $\begin{array}{l}4.26(3.19-6.70) 0.000 \\
0.000\end{array}$ & $\begin{array}{l}3.33(2.39-4.63) 0.000 \\
0.000\end{array}$ \\
\hline HWE & 33 & $8101 / 7215$ & $\begin{array}{l}2.38(2,01-2.82) 0.000 \\
0.000\end{array}$ & $\begin{array}{l}1.78(1,48-2.13) 0.000 \\
0.000\end{array}$ & $\begin{array}{l}2.53(2,04-3.14) 0.000 \\
0.000\end{array}$ & $\begin{array}{l}5.20(3,63-7.46) 0.000 \\
0.000\end{array}$ & $\begin{array}{l}3.67(2.65-5.09) 0.000 \\
0.000\end{array}$ \\
\hline \multicolumn{8}{|l|}{ Ethnicity } \\
\hline Asian & 19 & $3424 / 4004$ & $\begin{array}{l}2.51(2.22-2.83) 0.000 \\
0.000\end{array}$ & $\begin{array}{l}1.65(1.46-1.86) 0.186 \\
0.000\end{array}$ & $\begin{array}{l}2.65(2.24-3.13) 0.012 \\
0.000\end{array}$ & $\begin{array}{l}5.28(4.28-6.51) 0.004 \\
0.000\end{array}$ & $\begin{array}{l}3.69(3.17-4.29) 0.013 \\
0.000\end{array}$ \\
\hline Caucasian & 14 & $4677 / 3211$ & $\begin{array}{l}2.17(1.53-3.10) 0.000 \\
0.000\end{array}$ & $\begin{array}{l}1.82(1.34-2.48) 0.000 \\
0.003\end{array}$ & $\begin{array}{l}2.15(1.46-3.17) 0.000 \\
0.000\end{array}$ & $\begin{array}{l}4.60(1.88- \\
11.24) 0.0000 .001\end{array}$ & $\begin{array}{l}3.61(1.56-8.35) 0.000 \\
0.003\end{array}$ \\
\hline \multicolumn{8}{|l|}{ SOC } \\
\hline HB & 22 & $3589 / 3273$ & $\begin{array}{l}2.29(1.77-2.97) 0.000 \\
0.000\end{array}$ & $\begin{array}{l}1.70(1.33-2.16) 0.000 \\
0.000\end{array}$ & $\begin{array}{l}2.44(1.82-3.27) 0.000 \\
0.000\end{array}$ & $\begin{array}{l}4.86(3.09-7.62) 0.000 \\
0.000\end{array}$ & $\begin{array}{l}3.47(2.37-5.09) 0.000 \\
0.000\end{array}$ \\
\hline $\mathrm{PB}$ & 11 & $4512 / 33942$ & $\begin{array}{l}2.50(2.10-2.97) 0.000 \\
0.000\end{array}$ & $\begin{array}{l}2.16(1.84-2.53) 0.021 \\
0.000\end{array}$ & $\begin{array}{l}2.73(2.24-3.32) 0.002 \\
0.000\end{array}$ & $\begin{array}{l}6.07(4.30-8.57) 0.002 \\
0.000\end{array}$ & $\begin{array}{l}4.26(3.22-5.64) 0.013 \\
0.000\end{array}$ \\
\hline \multicolumn{8}{|l|}{ AMD type } \\
\hline Wet & 17 & $3476 / 3579$ & $\begin{array}{l}3.03(2.59-3.55) 0.000 \\
0.000\end{array}$ & $\begin{array}{l}2.11(1.81-2.46) 0.138 \\
0.000\end{array}$ & $\begin{array}{l}3.40(2.90-3.99) 0.073 \\
0.000\end{array}$ & $\begin{array}{l}7.65(5.73- \\
10.21) 0.0090 .000\end{array}$ & $\begin{array}{l}4.65(3.72-5.82) 0.008 \\
0.000\end{array}$ \\
\hline Dry & 5 & $462 / 848$ & $\begin{array}{l}2.36(1.71-3.24) 0.750 \\
0.000\end{array}$ & $\begin{array}{l}1.33(0.76-2.32) 0.705 \\
0.316\end{array}$ & $\begin{array}{l}2.08(1.24-3.48) 0.618 \\
0.005\end{array}$ & $\begin{array}{l}6.01(3.05- \\
11.87) 0.8890 .000\end{array}$ & $\begin{array}{l}4.77(2.79-8.16) 0.964 \\
0.000\end{array}$ \\
\hline \multicolumn{8}{|l|}{ Genotyping } \\
\hline Others & 5 & $3004 / 2599$ & $\begin{array}{l}2.34(2.12-2.58) 0.219 \\
0.000\end{array}$ & $\begin{array}{l}1.83(1.32-2.52) 0.018 \\
0.000\end{array}$ & $\begin{array}{l}2.57(2.22-2.98) 0.176 \\
0.000\end{array}$ & $\begin{array}{l}6.25(4.26-9.15) 0.005 \\
0.000\end{array}$ & $\begin{array}{l}3.56(2.97-4.27) 0.144 \\
0.000\end{array}$ \\
\hline Sequencing & 14 & $2613 / 2332$ & $\begin{array}{l}2.84(2.61-3.09) 0.237 \\
0.000\end{array}$ & $\begin{array}{l}2.08(1.81-2.41) 0.252 \\
0.000\end{array}$ & $\begin{array}{l}3.19(2.79-3.65) 0.710 \\
0.000\end{array}$ & $\begin{array}{l}7.00(5.84-8.39) 0.677 \\
0.000\end{array}$ & $\begin{array}{l}4.51(3.90-5.21) 0.169 \\
0.000\end{array}$ \\
\hline TaqMan & 4 & $591 / 524$ & $\begin{array}{l}2.66(1.43-4.94) 0.000 \\
0.002\end{array}$ & $\begin{array}{l}2.79(1.31-5.91) 0.000 \\
0.008\end{array}$ & $\begin{array}{l}3.61(1.52-8.60) 0.000 \\
0.004\end{array}$ & $\begin{array}{l}7.52(2.05- \\
27.68) 0.0000 .002\end{array}$ & $\begin{array}{l}3.86(1.66-8.98) 0.002 \\
0.002\end{array}$ \\
\hline PCR-RFLP & 6 & $1037 / 1121$ & $\begin{array}{l}2.01(1.77-2.28) 0.144 \\
0.000\end{array}$ & $\begin{array}{l}1.72(1.42-2.07) 0.610 \\
0.000\end{array}$ & $\begin{array}{l}2.08(1.74-2.48) 0.539 \\
0.000\end{array}$ & $\begin{array}{l}4.30(2.51-7.35) 0.073 \\
0.000\end{array}$ & $\begin{array}{l}3.41(2.62-4.43) 0.153 \\
0.000\end{array}$ \\
\hline RT-PCR & 2 & $509 / 293$ & $\begin{array}{l}0.88(0.12-6.27) 0.000 \\
0.900\end{array}$ & $\begin{array}{l}0.53(0.08-3.57) 0.010 \\
0.516\end{array}$ & $\begin{array}{l}0.54(0.03-8.51) 0.000 \\
0.663\end{array}$ & $\begin{array}{l}0.97(0.01- \\
32.38) 0.0010 .989\end{array}$ & $\begin{array}{l}1.37(0.05- \\
38.98) 0.0190 .852\end{array}$ \\
\hline $\begin{array}{l}\text { MassARRAY } \\
\text { MALDI-TOF }\end{array}$ & 2 & $347 / 346$ & $\begin{array}{l}2.18(1.39-3.49) 0.043 \\
0.001\end{array}$ & $\begin{array}{l}1.46(0.95-2.24) 0.213 \\
0.088\end{array}$ & $\begin{array}{l}2.22(1.13-4.38) 0.099 \\
0.021\end{array}$ & $\begin{array}{l}3.84(1.53-9.63) 0.044 \\
0.004\end{array}$ & $\begin{array}{l}3.05(1.78-5.23) 0.097 \\
0.000\end{array}$ \\
\hline
\end{tabular}

$P_{\mathrm{h}}$ : value of $Q$-test for heterogeneity test; $P$ : Z-test for the statistical significance of the OR

Table 4 Publication bias tests (Begg's funnel plot and Egger's test for publication bias test) for HTRA1 rs11200638 polymorphism. 


\begin{tabular}{|c|c|c|c|c|c|c|c|}
\hline \multicolumn{6}{|l|}{ Egger's test } & \multicolumn{2}{|c|}{ Begg's test } \\
\hline Genetic type & Coefficien $t$ & Standard error & $t$ & $P$ value & $95 \% \mathrm{CI}$ of intercept & $z$ & $P$ value \\
\hline A-allele vs. G-allele & 1.181 & 2.034 & 0.89 & 0.38 & $(-2.367-5.996)$ & 0.85 & 0.396 \\
\hline AG vs. GG & 0.104 & 0.835 & 0.12 & 0.902 & $(-1.612-1.820)$ & 0.18 & 0.859 \\
\hline $\mathrm{AA}+\mathrm{AG}$ vs. $\mathrm{GG}$ & 0.058 & 0.879 & 0.07 & 0.948 & $(-1.748-1.865)$ & 0.14 & 0.89 \\
\hline AA vs. GG & 0.302 & 0.712 & 0.42 & 0.675 & $(-1.162-1.766)$ & 0.26 & 0.797 \\
\hline AA vs. $A G+G G$ & 1.92 & 1.148 & 1.67 & 0.106 & $(-0.440-4.280)$ & 0.45 & 0.65 \\
\hline
\end{tabular}

\section{Figures}

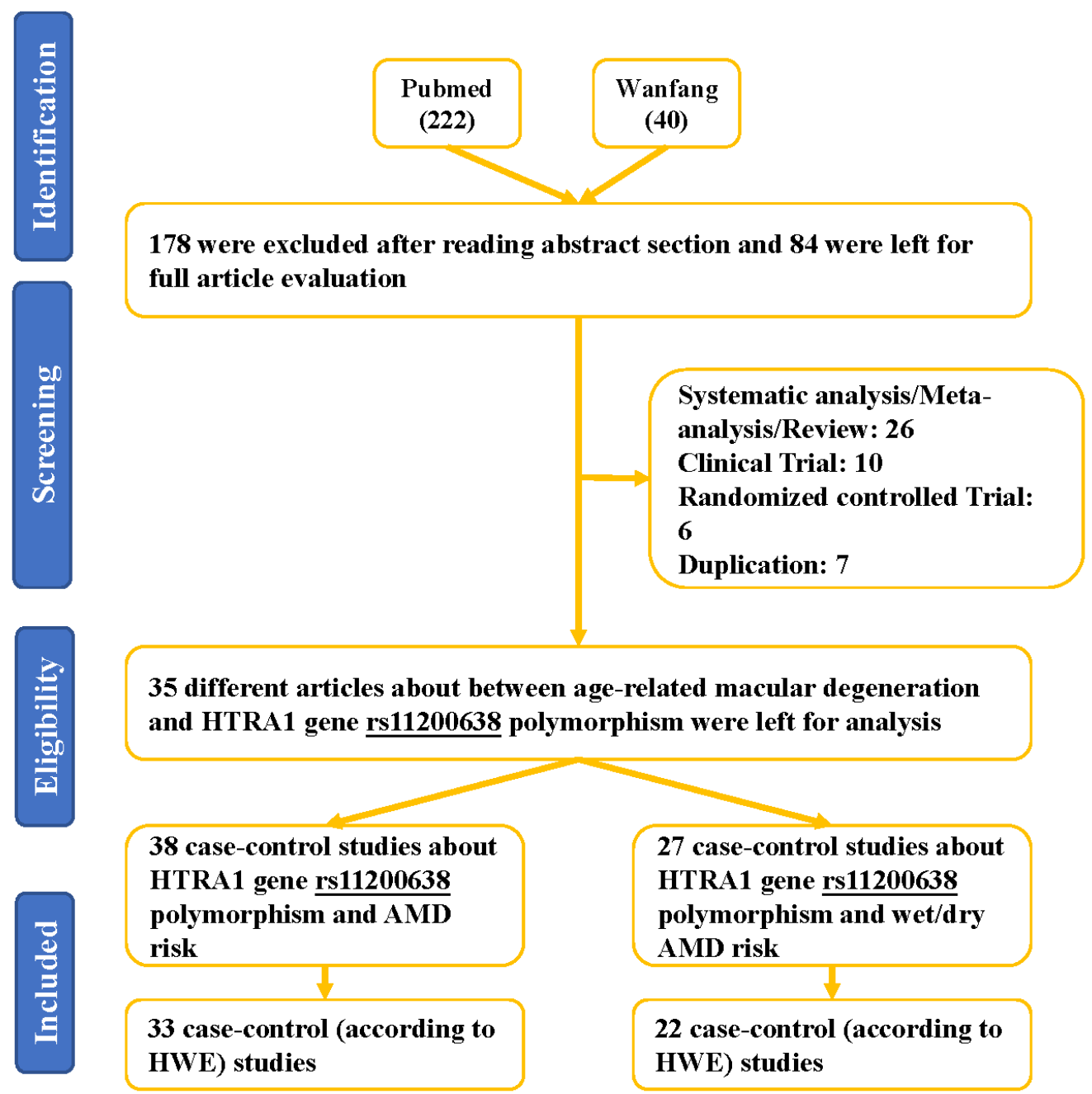

Figure 1

Flowchart illustrating the search strategy used to identify association studies for HTRA1 gene rs11200638 polymorphism and AMD risk. 


\section{rs11200638}

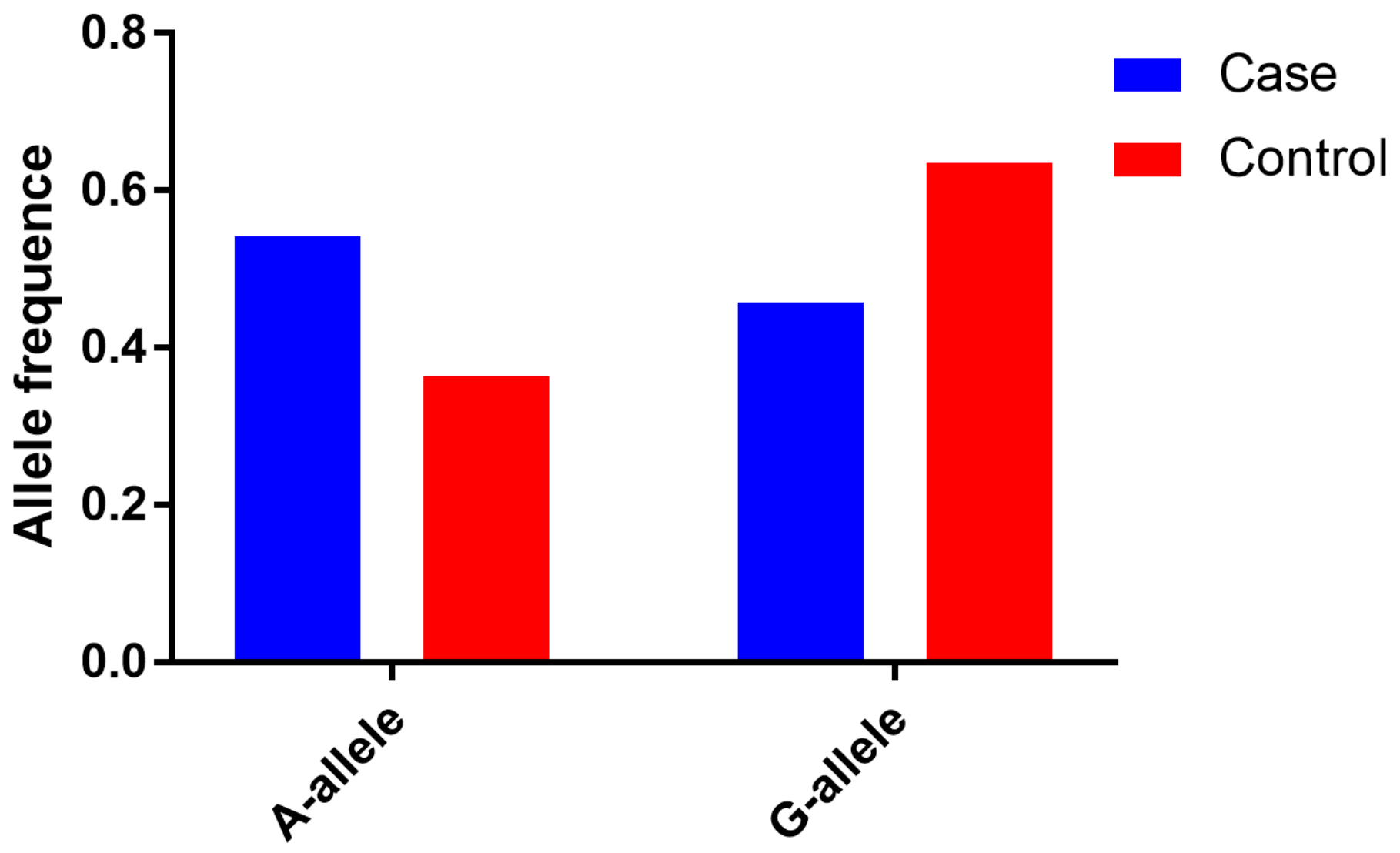

Figure 2

The MAF of minor-allele (mutant-allele) for HTRA1 gene rs 11200638 polymorphism from the 1000 Genomes online database and present analysis. EAS: East Asian; EUR: European; AFR: African; AMR: American; SAS: South Asian. 


\section{rs11200638}

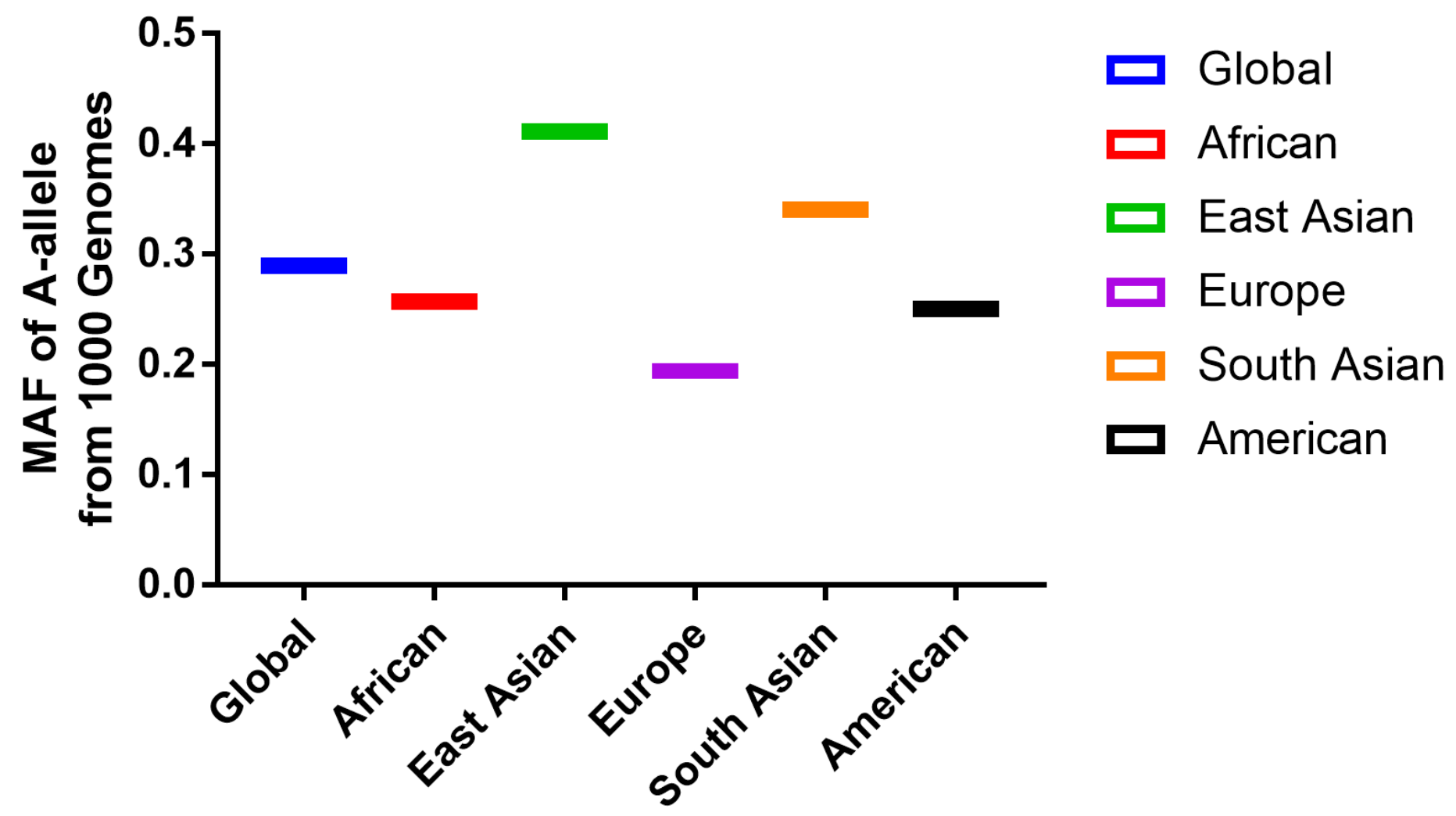

Ethnicity

Figure 3

A-allele frequencies for the HTRA1 gene rs11200638 polymorphism among cases/controls stratified by ethnicity. Vertical line, allele frequency; Horizontal line, case/control groups. 


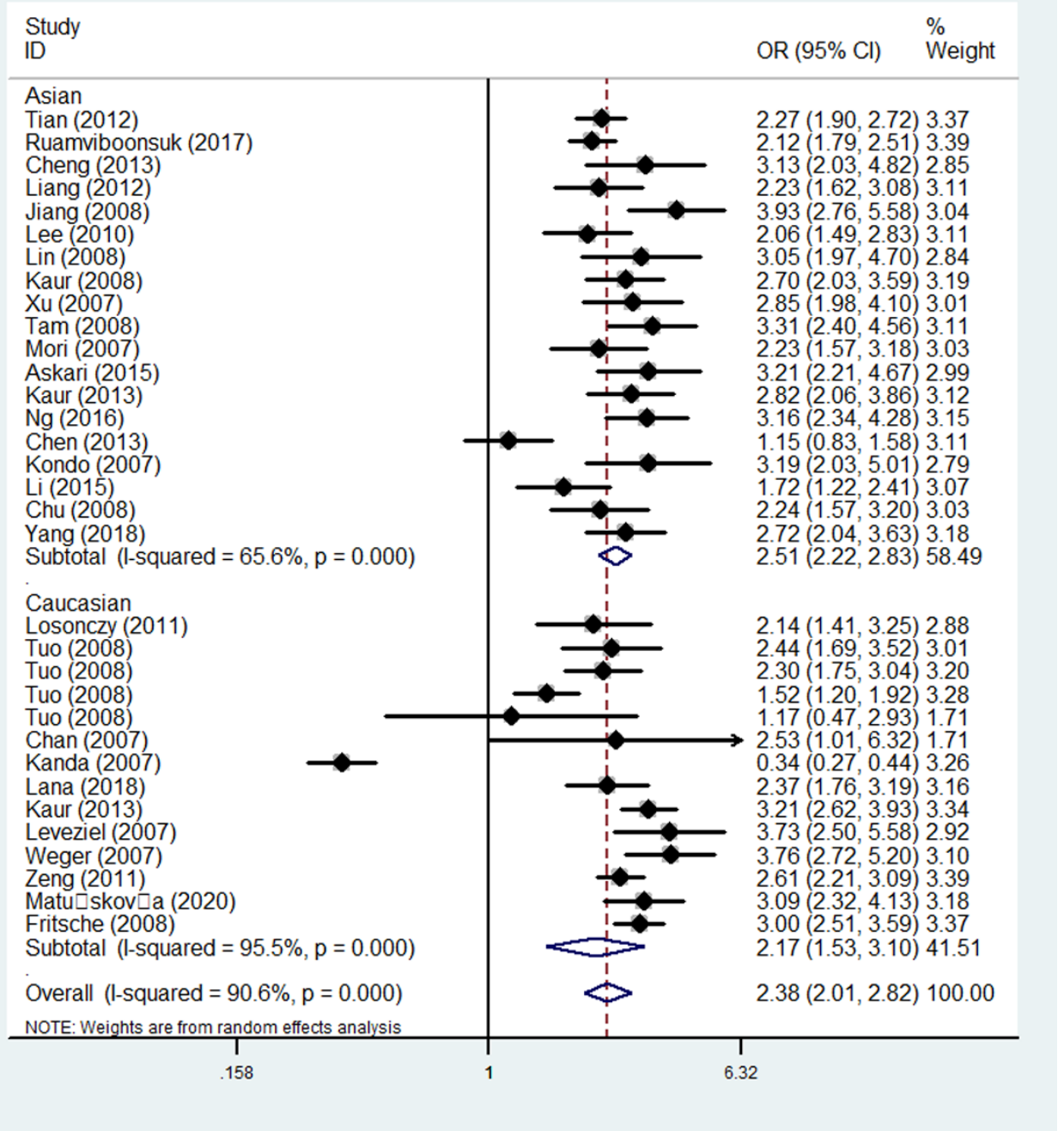

\section{Figure 4}

Forest plot of AMD risk associated with HTRA1 gene rs11200638 polymorphism (A-allele vs. G-allele) by ethnicity subgroup. The squares and horizontal lines correspond to the study-specific OR and $95 \% \mathrm{Cl}$. The area of the squares reflects the weight (inverse of the variance). The diamond represents the summary OR and $95 \% \mathrm{Cl}$. 


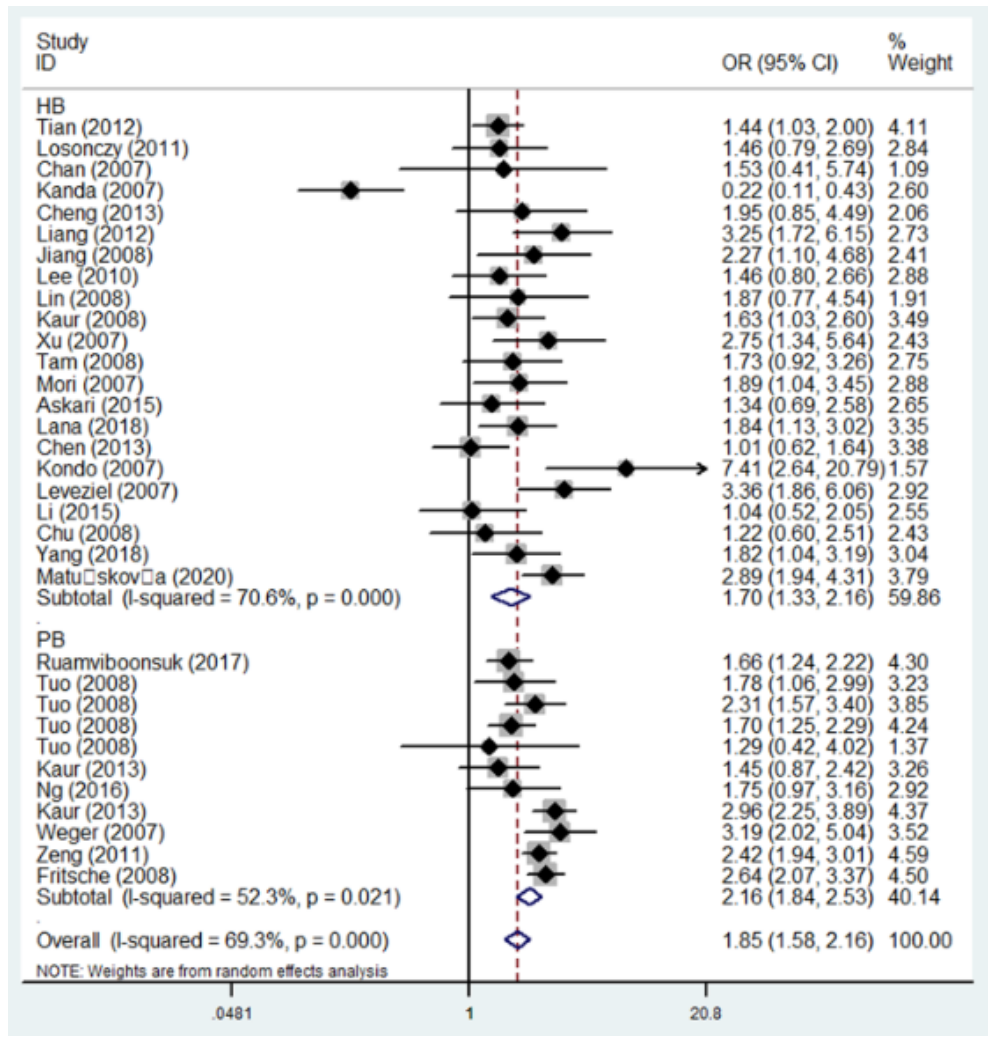

\section{Figure 5}

Forest plot of AMD risk associated with HTRA1 gene rs11200638 polymorphism (AG vs. GG) by source of control subgroup.

A

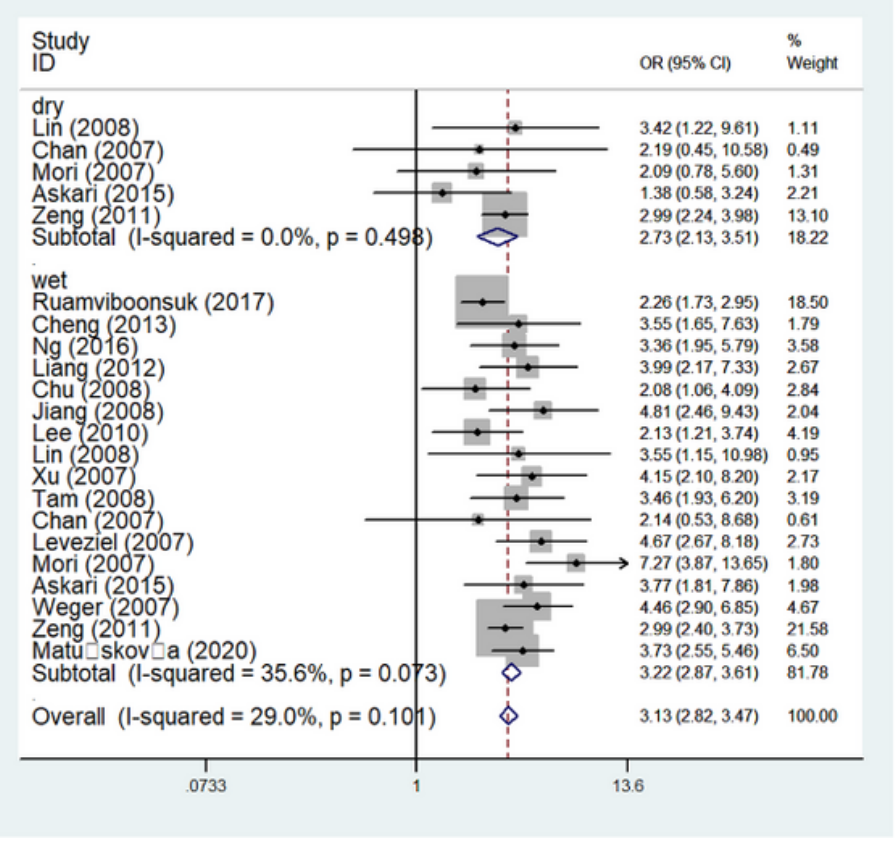

B

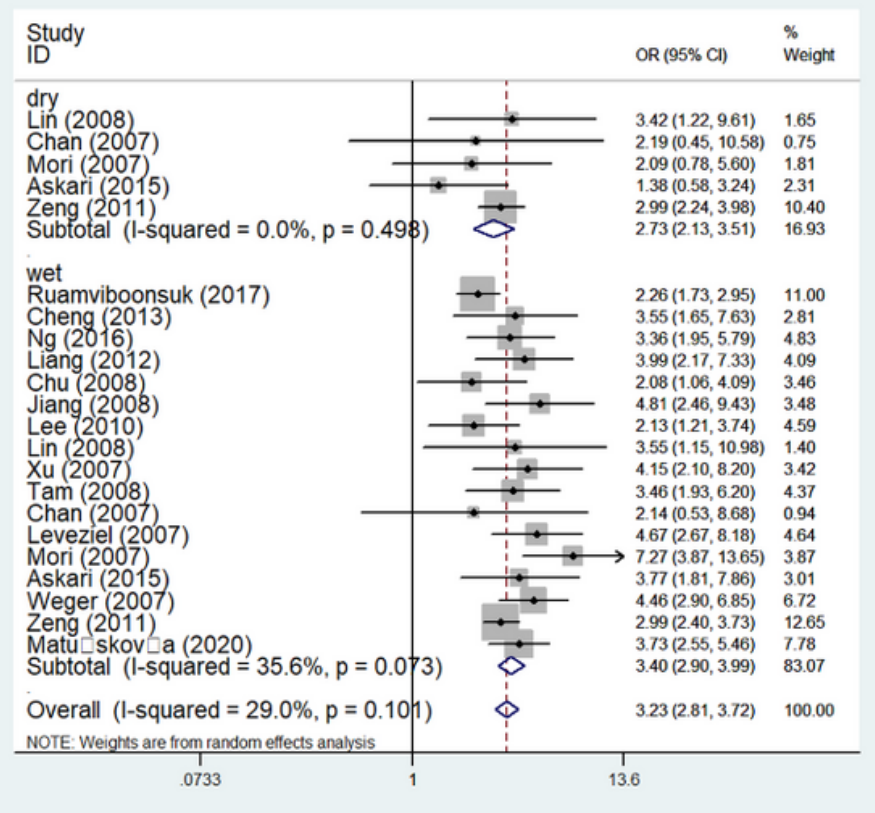

Figure 6

Forest plot of AMD risk associated with HTRA1 gene rs11200638 polymorphism (AA+AG vs. GG) by AMD type subgroup. A: wet AMD; B: dry AMD. 
A

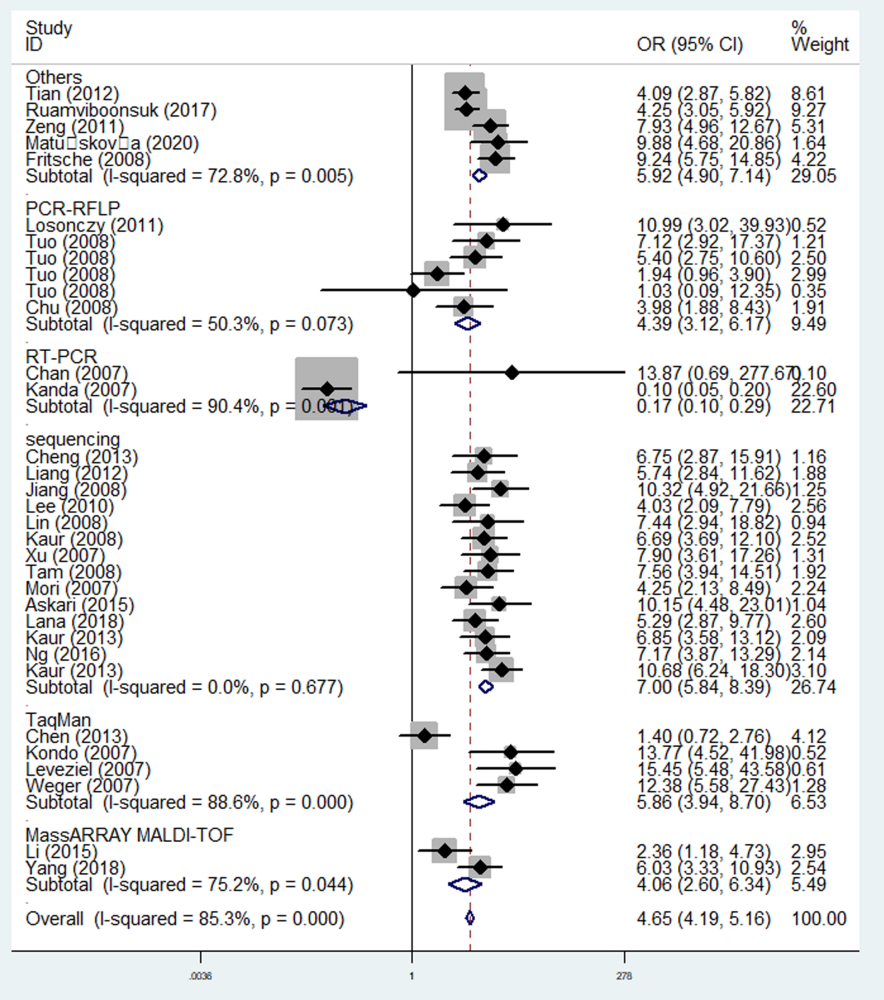

B

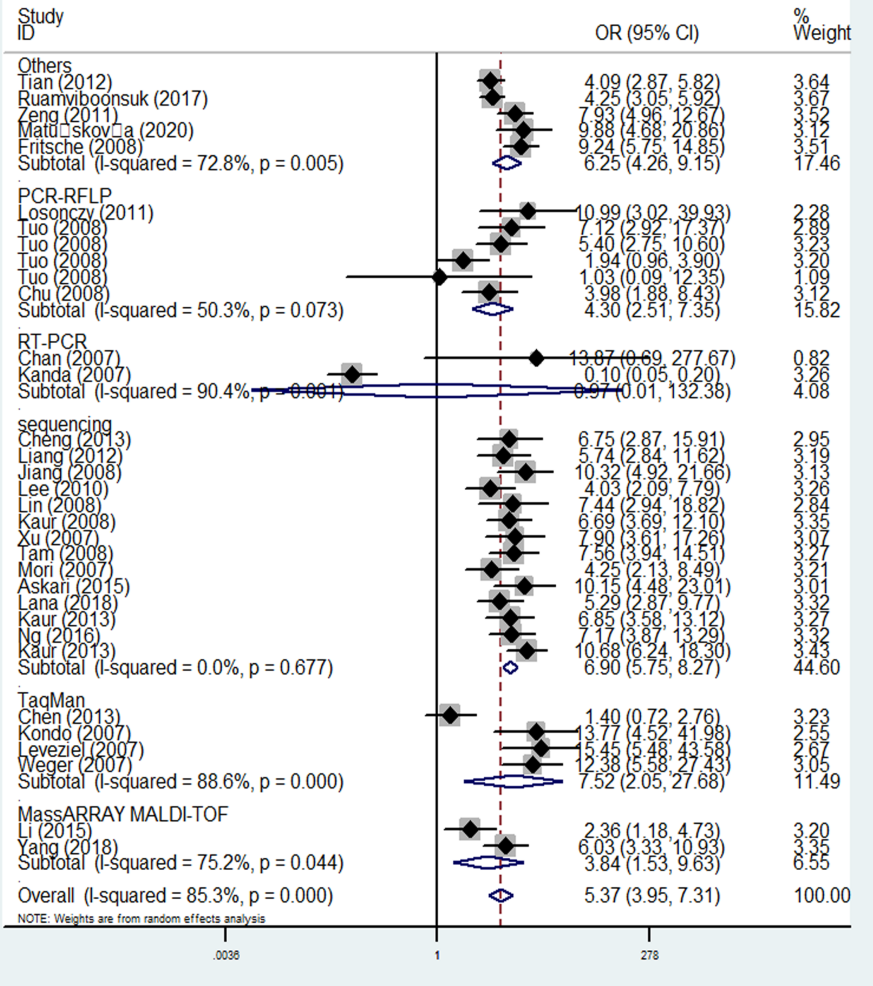

Figure 7

Forest plot of AMD risk associated with HTRA1 gene rs11200638 polymorphism (AA vs. GG) by genotyping methods subgroup. A: random model; B: fixed model.
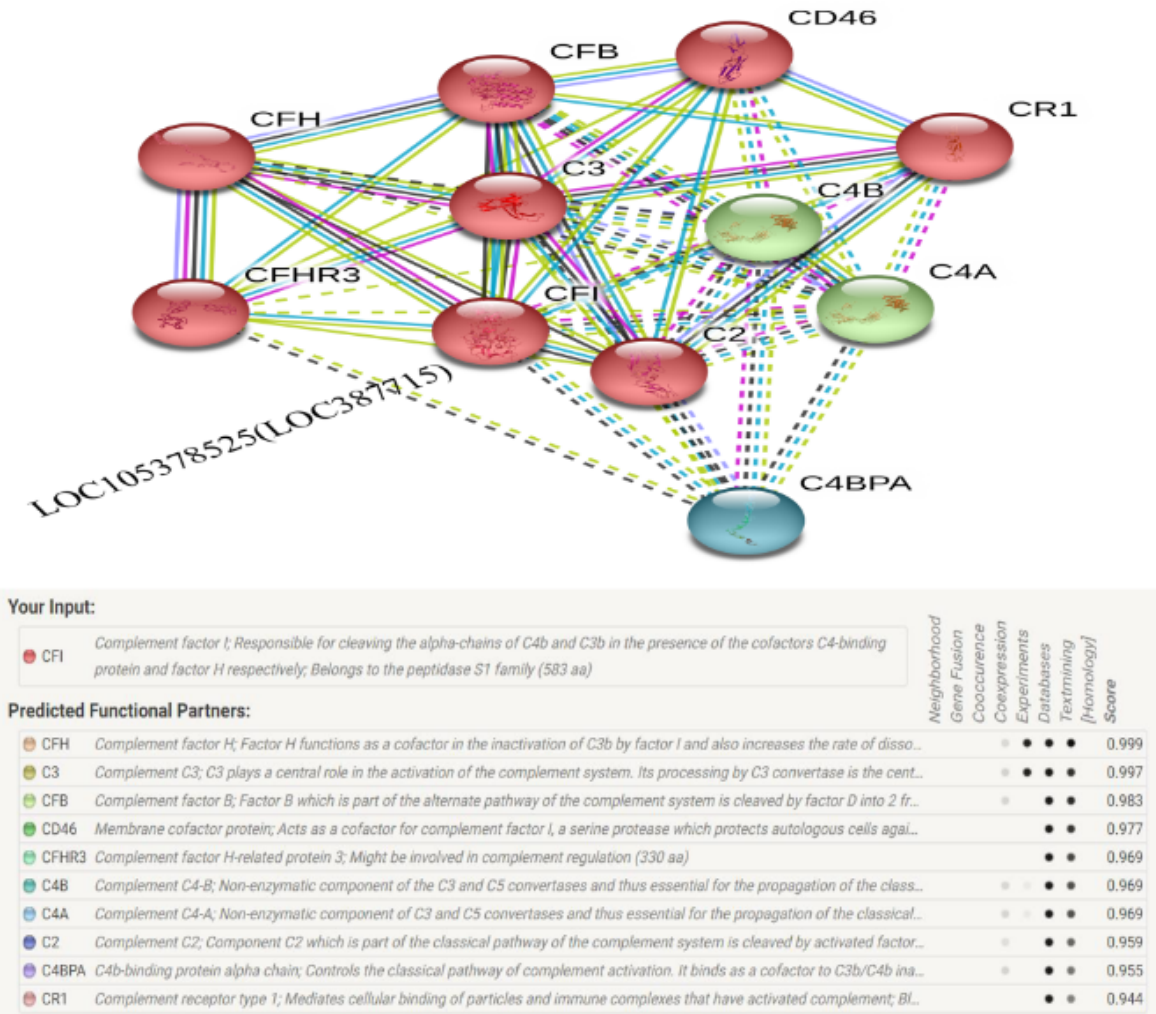

LOC105378525(LOC387715) gene were definited from Kanda et al. (2007) 
Human HTRA1 interactions network with other genes obtained from String server. At least 10 genes have been indicated to correlate with HTRA1 gene. ACAN: aggrecan core protein; ARMS2: age-related maculopathy susceptibility; CLPP: ATP-dependent Clp protease proteolytic subunit; CTRC: chymotrypsin-C; YME1L1: ATP-dependent zine metalloprotease YME1L1; CFH: complement factor H; HSPD1: 60 kDa heat shock protein; RPL34: 60S ribosomal protein L34; CLPX: ATP-dependent Clp protease ATP-binding subunit clpX-like; PLEKHG4: Puratrophin-1.

\section{Supplementary Files}

This is a list of supplementary files associated with this preprint. Click to download.

- SupplemmentaryFigure2.tif

- SupplemmentaryFigure1.tif 